\title{
Interactive comment on "Oil palm modelling in the global land-surface model ORCHIDEE-MICT" by Yidi Xu et al.
}

Yidi Xu et al.

xuyd18@mails.tsinghua.edu.cn

Received and published: 5 April 2021

We thank the referee for reviewing our manuscript. Please find attached a point-by point reply to each of the comments raised by the referee.

Please also note the supplement to this comment:

https://gmd.copernicus.org/preprints/gmd-2020-252/gmd-2020-252-AC2-

supplement.pdf

Interactive comment on Geosci. Model Dev. Discuss., https://doi.org/10.5194/gmd-2020-252, 2020. 